\title{
Banking efficiency, governance and financial regulation in Brazil
}

\section{LUIZ FERNANDO DE PAULA*}

In this short paper I analyze briefly some issues that I consider important for the discussion related to the banking efficiency, governance and financial regulation, with special focus on Brazil. The subject is complex as involve different dimensions and I will explore here only some of them, some related to past researches other ones that should be explored in further research. First of all, the focus here is banking activity. I will not consider an important dimension related to financial regulation and financial efficiency in Brazil that is capital account liberalization and capital controls. My own contribution on this latter theme is consolidated in the book "Financial Liberalization and Economic Performance: Brazil at the Crossroads" (Paula, 2011), and I would like to explore here new ways and other subjects.

The paper is divided in three sections. First section discusses the concept of financial efficiency. Second section analyzes the evolution of the Brazilian financial system since the 1960s and shows how 'dysfunctional' it has been. In third section we discuss some structural and recent issues related to the efficiency of banking sector in Brazil.

\section{THE EFFICIENCY OF THE FINANCIAL SYSTEM: A CONCEPTUAL ANALYSIS}

In order to discuss financial efficiency we should consider the different dimensions of banking efficiency. In general, the studies refer mainly to operational efficiency, focusing on the cost dimension of the intermediation function of the intermediary institutions. Under this more conventional approach the main focus of the

\footnotetext{
* Full Professor of Economics at the University of the State of Rio de Janeiro, and CNPq researcher. E-mail: luizfpaula@terra.com.br.
} 
(empirical) analysis is to measure scale efficiency or scope efficiency derived from banking mergers and acquisitions. Such economies can have positive effects on the financial intermediation, when cost economies are translated to lower net interest margins - that is economic agents could reap the benefits of the lower interest rate derived from greater efficiency and greater financial diversification (in terms of financial products). Another stream of studies consider that empirically there is a robust and strong relationship between development of financial system and economic growth, although theoretically they have not advanced so much due to the own limits of the conventional theory that consider banks as 'neutral' financial intermediaries.

We consider, however, that financial efficiency has to be understood as a broader concept. Our departure point is that the Keynesian concept of 'financial functionality' as synthesized by Studart (1995, p. 64):

Functionality is defined as follows: a financial system is functional to the process of economic development when it expands the use of existing resources in the process of economic development with the minimum possible increase in financial fragility and other imbalances, that may halt the process of growth for purely financial reasons.

One important consequence of this theoretical approach is that although investments decisions determined by the entrepreneur long-term expectations generate their own aggregate savings, the development of financial system is very important to support economic growth in order to avoid some financial constraint that can halt investment decisions, and to channel ex post savings to fund the short-term firms' liabilities in better conditions (to reduce the firm's financial fragility). A functional financial system is a financial system that performs both functions of finance and funding of the investment, giving support to a financially stable growth. There is clearly a Keynes' dimension - the importance of the financial system to solve the issues related to financial constraints to investments - and Minsky's dimension - financial system can contribute to increase or reduce financial fragility of the economy - involved in such definition. Financial system can be a source of economic growth but at the same time can be a source of instability.

So, regarding financial efficiency as a multidimensional concept, we can divide for simplest purposes in macroeconomic dimension and microeconomic dimension. The macroeconomic dimension of the efficiency of the banking sector is related to the support of the stability of the financial system as a whole and its skill to create funds to give support to the expenditures decisions of the economic agents (firms and households). In other words, it refers to how the financial system financially supports a stable economic growth. The microeconomic dimension is related to the skill of the financial system to supply financing to investors and other agents at the lesser possible costs. Therefore, broadly speaking, a functional financial system - integrating both macro and micro dimension - is that able to expand with flexibility the supply of financial resources in the economy with minimum possible 
financial fragility at reduced financing costs. Although both dimensions of the efficiency of the financial system are related it is possible to have situations in which the financial system is efficient from micro point of view, but it is not efficient in the macro dimension - as we will see is typically the case of the Brazil in the 1980s-1990s. Another aspect of the discussion of the functionality of the financial system is related to the allocation dimension in terms of who have access to the credit. This dimension is important due to the recent overall changes in the financial systems in the worldwide scale. Banking consolidation that has resulted from the wave of banking mergers and acquisitions (M\&As) and banks' customer diversification (including the incorporation of a greater number of clients) have often generated a process of 'financial exclusion' and 'financial exploitation', in particular in developing countries. Examples of such process include the reduction of credit supply to middle and small firms and/or for geographic regions of lesser income that has followed M\&As (big banks buying regional small ones) in some developing countries (typically the case of Latin-American countries - see Dages et al., 2000), and also banks charging higher fees and interest rates on lower income customers (individuals and firms), compared to other customers.

\section{THE EVOLUTION OF THE FINANCIAL SYSTEM IN BRAZIL AND ITS FUNCTIONALITY}

Let me focus briefly in the Brazilian experience. The lack of private domestic structure is old problem of the domestic financial system, and it is the main evidence that financial system in Brazil has been non-functional for economic growth, in the terms defined above. In 1964-1967 Brazilian government implemented a set of financial reforms, that included a banking reform inspired in the North-American segmentation of the financial system, and some measures aiming at stimulating capital markets. Although the development of a private financial system contributed to financing of the economy (housing and vehicles/durables goods' credit), the long-term firms' financing relied on combination of self-financing, public credit and foreign capital, with a very low weight of the private domestic financing (both considering banking sector and capital markets). Since then, Brazil has a bank credit-based system, but with an important presence of state-owned banks playing an important role in long-term financing (investments, housing, and agriculture).

When Brazil was reached by the external debt crisis in the beginning of the 1980s, that eventually caused a huge fiscal crisis, the non-functionality of the financial system was evident, and aggravated by the fact that government could not play its role to support growth due to the deterioration of fiscal conditions. High inflation was the 'price' paid by debt external crisis and fiscal crisis, that resulted in the 1980s lost decade. Under such environment, the existence of 'indexed money' (short-term domestic-denominated financial assets, i.e., quasi-money, which were in most indexed to overnight rates of interest) was responsible for the maintenance of the savings in the domestic financial sector, avoiding the des-monetization and 
consequently the dollarization of the Brazilian economy as occurred in Argentina and another countries in Latin America, submitted to high inflation experience. In this context, credit supply declined sharply and was most entirely short-term, but banks could survive very well thanks to the short-term and inflationary revenues. Interestingly Brazilian banking sector developed a technological expertise in the clearing system during the high inflation period in order to process quickly checks and other financial operations, that eventually become one the most developed of the world.

After the implementation of the Real Plan in 1994, the succession of external crisis (contagious of Mexican crisis, Asian crisis, Russian crisis, and the own Brazilian currency crisis in 1999 and 2002) marked a very unstable macroeconomic environment that once more hindered the development of financial relationship in the Brazilian economy. In 1995 the banking distress was responded by Brazilian government with the implementation of banking restructuring programs - to stimulate acquisitions of private banks in trouble (PROER) and to privatize various state-owned banks ( PROES $^{1}$ ), and with stimulus to a regulated entrance of foreign banks to strength the domestic financial system ${ }^{2}$. As a result of such programs and other regulatory measures, 1995 banking distress did not cause a banking crisis. More importantly, since the 1997 Asian crisis, Brazilian government offered the banking sector hedges against exchange devaluation and interest rate changes, by offering them public bonds indexed to the exchange rate and overnight interest rate. So banks could adopt a conservative financial posture, i.e., a high proportion of government securities in their portfolio, low levels of mismatch between assets and liabilities, and low leverage levels. Therefore, banks were able to afford risk aversion strategies, thanks to the availability of high-yielding, relatively risk-free government securities as an alternative to private sector lending.

In 2004 began a gradual and steady increase in the credit supply in Brazil, after years of stagnation that followed the Asian crisis, following economic growth that was favored by the benign international environment (large international liquidity, commodities boom and international price deflation). Indeed, the increase in the credit market and capital market (equities and private bonds) showed how a more stable macroeconomic environment can simulate the development of financial relationship in the Brazilian economy. The credit boom was commanded by domestic private banks, but in 2008-2010 federal state-owned banks (BNDES, Banco do Brasil and CEF) performed an important contra-cyclical role in the credit market, increasing steadily the credit supply while the loans' growth rate of the private banks

\footnotetext{
${ }^{1}$ PROES aims at privatizing public banks that belonged to the states' government, not including federal banks. In general, each state had one or more public bank (commercial and/or development bank).

${ }^{2}$ Foreign banks entry was carried out on a case-by-case basis, that is it depended on the Central Bank of Brazil authorization.
} 
was declining. Such role was one of the more important piece (if not the main piece) of the contra-cyclical measures adopted by the Brazilian government.

However, the 'preference for flexibility', that was typical of the high inflation environment, has been still present in the Brazilian economy. Corporate bonds (debentures), that is the main private debt bond issued in Brazil, have mostly been issued indexed to the interbank interest rate (DI), that is the interest rate defined in the banking reserves market. This means that financial fragility, due to the changes in the interest rates, is in hands of the issuer firm. Besides, credit banking has been mostly supplied with some sort of collateral (vehicles and payroll) or short-termist (firms' working capital and firms' overdraft account). High banking spread provides a high return to the banks with credit operation. In turn, the weight of foreign investors on Brazilian stock market increased substantially, which exposes this market to greater volatility and vulnerability. This scenario leads us to an important conclusion: although the response of the financial system to the recovery of Brazilian economy in recent years was positive, it is not sufficient to characterize a situation of 'high' functionality to economic development. Furthermore, Brazilian financial system is still crucially dependent of the state-owned banks, that as we have seen played a very important role to face the impacts of the international crisis.

\section{SOME STRUCTURAL AND RECENT ISSUES IN BRAZIL}

Now I will focus on some structural and recent issues related to the banking efficiency in Brazil. Firstly, let us consider as a matter of fact that banking sector in Brazil survived very well the succession of external crises, in particular since the contagious of the Asian crisis, and this is considered by some analysts as an evidence of how healthy is the Brazilian financial system due to a more tightened financial regulation. Indeed, the Basel Accord I was incorporated to the Brazilian regulation by the National Monetary Council, which established the minimum capital requirements ratio weighted by risk the bank's assets operation as $11 \%$, above the $8 \%$ that is the benchmark of Basel Accord. However, when we have a look on data, we can see that Brazilian banks surpass the level of capital requirement set forth in Basle I in Brazil far above the Brazil's minimum capital requirements ratio weighted of $11 \%$. One of the main reasons is that Brazilian banks portfolio is constituted partly by public federal bonds, that have zero risk. As we have seen Brazilian government since the contagious of the Asian crisis provided hedge to the banks against the exchange rate devaluation and interest rate increases. For this reason, the Brazilian banking sector did not face the classical liquidity-versus-profitability trade-off, as the institutional-macroeconomic context afforded an environment with scope for banks to combine liquidity and profitability. This is in my point of view one the main explanations as to why external crises did not caused a banking crisis in Brazil, at the cost of public finance deterioration in terms of increasing public debt.

Second, concerning foreign bank entry in the domestic banking sector, Brazilian 
government expected an improvement in operational efficiency of the banking sector with positive effects on bank intermediation, diversification and improvement of supply of financial services with lowest costs, and introduction of new management technologies and innovations in products and services. With foreign entry would come increased competition, and it was believed that foreign institutions were more efficient than their domestic counterparts. Empirical evidence shows that the expected benefits of foreign banks entering the domestic banking sector, such as new initiatives in the credit supply and lower net interest margins, did not materialized in the case of the Brazil. However, there is some empirical evidence that domestic private banks reacted the foreign bank entry increasing their operational efficiency (Paula, 2011).

Third, one distinguish feature of the Brazilian banking consolidation, that seems to have not similarity in other emerging countries that had in the 1990s an important foreign banks penetration in the domestic market, is the fact that private domestic banks (mainly Itaú and Bradesco) reacted the foreign bank penetration, and even commanded the process of banking M\&As in Brazil ${ }^{3}$. We consider three factors that contributed for the reaction of domestic private banks to foreign bank entry in Brazil. First, the fact that 1995 banking distress did not cause a banking crisis as it was the case of Argentina and Mexico, so that the domestic private banks that survived such distress, as it was the case of Itaú, Bradesco and Unibanco, took part actively of the wave of banking M\&As in Brazil. Indeed, the rapid response of Central Bank of Brazil in acting to avoid banking distress becoming a systemic crisis. Second, the fact that domestic banks accumulated technological and management capabilities during the high inflation period so that they are used to deal with unstable macroeconomic situations, as it was the case of the effects of the 1997 Asian crisis, 1998 Russian crisis, 2002-2003 Brazilian confidence crisis. Third, foreign bank entry was somehow limited in Brazil, that is it the permission for foreign bank was done case-by-case. Compared to Argentina and Mexico, banking sector opening was much less dramatic in Brazil, as this can done the difference in avoiding a capital flight commanded by foreign banks during external crises (as it was the case of Argentina in 2002).

Furthermore, when we consider the effects of banking consolidation in terms of the distribution of credit supply in Brazil, some studies show that banking consolidation has contributed to increase the regional credit distribution, that is credit supply is becoming even more concentrated in the most developed states of the country compared to the less developed ones (Gonçalves and Paula, 2010). The reason seems to be related, among other factors, to the fact that due to banking M\&As some regional banks have disappeared and branches network is increasing more in the developed states than in less developed ones.

Finally, there is also some evidence that universal banks in Brazil have ex-

\footnotetext{
${ }^{3}$ In 2009 domestic private banks had $42.1 \%$ of total assets of banking sector in Brazil, while foreign banks had only $20 \%$.
} 
panded their activities rapidly, even incorporating lower-income customers, but such incorporation has been done with practices that could be characterized as financial exploration, in the sense that banks charge high interest rates and high fees of such customers, in a strategy that can be called as 'debt trap'4.

\section{REFERENCES}

DAGES, B.G., GOLDBERG, L. and KINNEY, D. (2000). "Foreign and domestic bank participation in emerging markets: lessons from Mexico and Argentina”. FRBNY Economic Policy Review, pp. 17-36.

DYMSKI, G. (2007). "Exclusão e eficiência: a transformação global do core banking, um estudo de caso do Brasil”. In Paula, L.F. and Oreiro, J.L. (ed.). Sistema Financeiro. Rio de Janeiro: Campus/ Elsevier.

GONÇALVES, A.P. and PAULA, L.F. (2010). “Concentração regional do crédito e consolidação bancária no Brasil: uma análise pós-Real”. Revista Economia, 11(1): 97-123.

PAULA, L.F. (2011). Financial Liberalization and Economic Performance: Brazil at the Crossroads. Abingdon: Routledge.

STUDART, R. (1995). "The efficiency of financial systems, liberalization, and economic development". Journal of Post Keynesian Economics, 18, 269-292.

\footnotetext{
${ }^{4}$ According to Dimsky (2007, p. 273), a World Bank study "concludes that [in Brazil] low-income people pay more for basic banking services than do other households. One reason is that banking institutions often offer discounts for larger transactions. This is one manifestation of banks' segmentation of their customer markets. The banks are not interested in providing savings vehicles for lower-balance customers - they have segmented the markets and primarily are interested in fee-based current and savings-account relationships.”
} 